\title{
Spatial Analysis of Wildlife Habitat around Madihan forests of Mirzapur district, Uttar Pradesh in India, using Geospatial Technology
}

\author{
Laxmi Goparaju $\bowtie$, Firoz Ahmad, Debadityo Sinha
}

Vindhyan Ecology and Natural History Foundation, 36/30, Shivpuri Colony, Station Road, Mirzapur 231001, Uttar Pradesh, India, phone: +91 9540857338, e-mail: goparajulaxmi@yahoo.com

\begin{abstract}
The tropical dry deciduous forests of Mirzapur district in Uttar Pradesh (state) in India are facing to severe threat from agricultural expansion, increased urbanisation, infrastructure development and unsustainable use of forest produce. The forests are nowadays fragmented and wildlife habitat is vanishing. Decreasing numbers of wild animal species requires using methods for preventing the loss of biodiversity.

The present study concerns analysis of satellite remote sensing data of Landsat OLI (2013) in conjunction with Geographic Information System (GIS) and support of Geographic Positioning System (GPS) to identify suitable habitat for wild animals. The thematic maps regarding e.g. land use, forest cover type were prepared. The weighted overlay method was used for integration of the thematic layers for identification of potential habitat and corridors for wildlife movement. Most suitable (2.54\%), moderately suitable (12.0\%) and least suitable (16.20\%) areas were delineated and represented in a map. Highly suitable habitat was found at Dadri and Kotwa forest; moderately suitable habitat was found in Darhi Ram forests. Least suitable areas were found in Kotwa and Patewar forests. Such data are the basis to assess the wildlife conservation measures.
\end{abstract}

\section{KeY WORDS}

wildlife, Mirzapur, Geospatial, dry deciduous, habitat suitability, weighted overlay

\section{INTRODUCTION}

Tropical forests are more susceptible to degradation, depletion and conversion to other land uses and thus highly threatened and least protected ecosystems of the world (De Fries et al. 2005), and they are disappearing at an alarming rate owing to over exploitation of forest produce and lack of protection (Murphy and Lugo 1986; Raghubanshi and Tripathi 2009).
The forests of Mirzapur have eight forest ranges, namely, Madihan, Mirzapur, Chunar, Sukrit, Wyndham Fall, Patehra, Lalganj and Drammadganj. Chandraprabha and Kaimur wildlife sanctuary are present on either side. They mark the advent of one of the oldest mountain ranges of India, the Vindhyan range (Akhtar et al. 2004). The forests are facing various degrees of anthropogenic disturbance and are in various stages of forest fragmentation and degradation. Land use and land cover of this 
region have witnessed drastic changes since 2010-2013 as reported by Goparaju and Sinha 2015. Lack of proper knowledge and database of wildlife species in this area has handicapped the conservation efforts. The greatest challenge to preserve wildlife is to maintain biological integrity of the surrounding habitat mosaic and connectivity between the remnant core areas to maintain vital ecological connections by providing physical linkages between these areas (Mondol et al. 2010; Kamat 1986).

Traditional methods and ground-based studies have been used in studying wildlife habitat and corridor use (Bhat and Rawat 1995; Johnsingh and Joshua 1994; Mishra and Johnsingh 1996). They are time consuming and inefficient in hilly and inaccessible areas. Satellite remote sensing provides us data at regular intervals and of different spatial and spectral resolution when in Geographic Information System (GIS) domain to achieve a particular target. Studies in wildlife using geospatial technology have been gaining importance since the past few decades in India and have emphasised its role in habitat evaluation, identification and management of wildlife corridors (Khanna et al. 2001; Kushwaha and Hazarika 2004; Nandy et al. 2007). Remotely sensed data helps in identifying changes in land use/land cover, habitat attributes, new locations for protected areas and current scenario of wildlife corridors (Kamat 1986); to monitor ecological impacts and changes within corridors; and to provide capabilities to study and interpret wildlife habitat info on different time scales (Yadav et al. 2011; Areendran et al. 2011; Nandy et al. 2007).

The aim of the study concerns the identification of potential habitats for wild animals in and around Madihan forests in Mirzapur district, Uttar Pradesh (India) and to identify suitable corridors (reintegration of forest patches) for wildlife movement and their conservation.

\section{MATERIAL AND METHODS}

The study was carried out in Madihan forest range in Mirzapur district in Uttar Pradesh (state) in India, which lies between $25^{\circ} 0^{\prime} 8.83^{\prime \prime} \mathrm{N}$ to $24^{\circ} 56^{\prime} 37.61^{\prime \prime} \mathrm{N}$ and $82^{\circ} 37^{\prime} 31.91^{\prime \prime} \mathrm{E}$ to $82^{\circ} 45^{\prime} 59.10^{\prime \prime} \mathrm{E}$. The climate here is characterised by three distinct seasons: the summer season (March to June) is hot and dry when temperatures can reach as high as $48{ }^{\circ} \mathrm{C}$; warm and humid rainy season (July to October) during which rainfall varies from 90 to $100 \mathrm{~cm}$; and cool dry winter (November to February) when temperatures can be as low as $6{ }^{\circ} \mathrm{C}$ (Singh 2007). The soil varies from loamy sand to clay. Variation in colour of soil is observed from red to yellow (Das et al. 2007). The terrain is undulating with hillocks dominating (Fig. 1).

The forests of this region are best described as tropical dry deciduous forest (Champion and Seth 1968). Large areas are of $5 \mathrm{~A} / \mathrm{C} 3$ and $5 \mathrm{~B} / \mathrm{C} 2$ types of forests, that is, Southern and Northern Tropical Dry Deciduous Forests, respectively. The flora is dominated by tree species such as Shorea robusta, Boswellia serrata, Anogeissus latifolia, Terminalia arjuna, Lagerstroemia parviflora, Hardwickia binnata, Acacia catechu, Butea monosperma, Zizyphus glaberrima, Diopsyros melanoxylon, Pterocarpus marsupium, Holorrhena antidysentrica, Emblica officinalis, Synzygium cumini, Tectona grandis and Madhuca longifolia.

The suitable atmosphere provided by the hot and dry climate and tree species such as D. melanoxylon, Zizyphus mauritina, Cassia fistula, Aegle marmelos, Buchnania lanzen and Zizyphus oenophila provide food and shelter to the animals. The fauna constitutes wild animals such as sloth bear, leopard, sambhar, black buck, chinkara, monkeys, langurs peafowl, Bengal monitor, mugger crocodile, nilgai and so on, which have their habitat in these forests.

\section{Image processing and classification}

The Landsat OLI (dated 25 November 2013; Path/Row 142/43) data were selected. It was taken care to choose a cloud free data for analysis. The data downloaded from the portal of United States Geological Survey (USGS) were geo-referenced and radiometrically corrected at the preliminary stage. Eleven bands were obtained in TIFF format, which were layer stacked to produce a composite image and then converted into IMG format for further analysis. The projection details are as follows: Projection UTM, Zone 44; Spheroid, WGS 84; Datum, WGS 84. Image processing software used is ERDAS imaging (version 9.0) and ARC GIS spatial analyst (version 10.0).

Thematic maps such as land use/land cover and forest cover map were prepared after image processing techniques were applied for the above data. Other thematic layers such as road and streams were downloaded from DIVA - GIS. Elevation data (Digital Elevation Model, DEM) were also downloaded from ASTER DEM. 


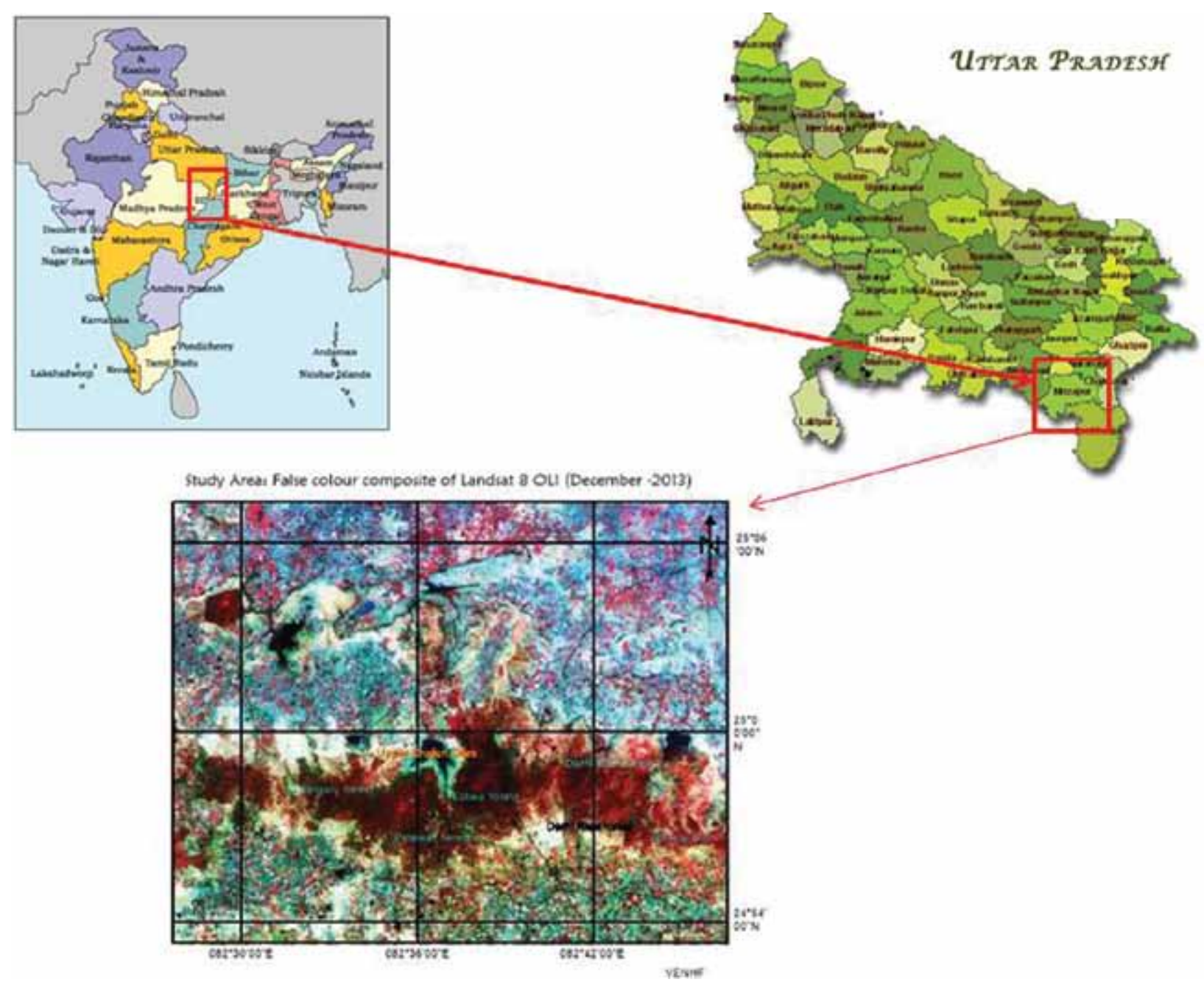

Figure 1. Location of the study area

\section{Field data collection}

Using GPS during field survey, sighting location amidst forest patches were tracked and noted along patches of forests, grasslands and reservoirs. For tracking our route, it was used an advanced android tablet of make Samsung Tab 2 ver. 7.0 model GT-P3110, which has been an in-built satellite GPS-enabled system. The tablet was able to lock satellites within $30 \mathrm{~s}$ to $2 \mathrm{~min}$, and it gave resolution of up to $5 \mathrm{~m}$ during our field survey. A free android app named 'AndroiTS GPS Test' was used to trace locations, record our track and mark areas where anything specific was observed. The location was further supplemented by GPS-enabled camera manufactured by Sony, model no. HX400V, which would record GPS coordinates of all photographs taken.
The saved co-ordinates were converted into KMZ file on Google Earth. Later, the KMZ file was converted into Shape file in ARC GIS (version 10.0), which was used for further analysis. Buffer of this GPS sighting (buffer of line) was generated. The weights assigned are given in Table 1.

Table 1. Weights assigned for GPS sighting buffer

\begin{tabular}{|l|c|}
\hline \multicolumn{1}{|c|}{ GPS sighting buffer } & Assigned weight \\
\hline Buffer $0-500 \mathrm{~m}$ & 9 \\
\hline Buffer $500-1,000 \mathrm{~m}$ & 7 \\
\hline Buffer $1,000-1,500 \mathrm{~m}$ & 5 \\
\hline Outside 1,500 buffer & 2 \\
\hline
\end{tabular}




\section{Land use/Land cover classification}

To delineate various land use and land cover classes, visual interpretation technique in image processing was used. Various land form features were identified from false colour composite (FCC) using the photographic and geotechnical elements (Lillisend and Keifer 2004; Javed and Khan 2012). Five-six training sets were given for each class to capture the variation in the scene, based on the field knowledge and visual interpretation, and later merged to form a single representative class. Furthermore, supervised classification using maximum likelihood algorithm was executed to delineate five major land use/land cover classes, agriculture/fallow/settlement; fallow/urban/settlement; open fallow; water; dense forest and open forest. The accuracy of the classified data set was $88.67 \%$ (Goparaju and Sinha 2015). The weights assigned are given in Table 2 .

Table 2. Weights assigned for land use/land cover class

\begin{tabular}{|l|c|}
\hline \multicolumn{1}{|c|}{ Land use/land cover class } & Assigned weight (scale 1-9) \\
\hline Agriculture/settlements & 2 \\
\hline Fallow/urban/agriculture & 2 \\
\hline Open fallow & 3 \\
\hline Open forest & 7 \\
\hline Dense forest & 9 \\
\hline
\end{tabular}

\section{Forest cover classification}

Forest cover classes were derived by masking out the forest area from FCC. An unsupervised classification executed exclusively on the forest area yielded 10 forest cover classes spectrally. The accuracy of the classified

Table 3. Weights assigned for Forest class

\begin{tabular}{|l|c|}
\hline \multicolumn{1}{|c|}{ Forest class } & Assigned weight (scale 1-9) \\
\hline Dense forest/plantation & 9 \\
\hline Dense mixed forest & 8 \\
\hline open mixed forest & 7 \\
\hline Shrubland & 6 \\
\hline Degraded forest & 3 \\
\hline $\begin{array}{l}\text { Fragmented mixed forest } \\
\text { patches }\end{array}$ & 5 \\
\hline Open scrub & 2 \\
\hline Scrubland & 3 \\
\hline Grassland & 2 \\
\hline Woodland & 2 \\
\hline
\end{tabular}

data set is $89.31 \%$. The classes are (1) dense forest/plantation, (2) dense mixed forest, (3) open mixed forest, (4) shrubland, (5) degraded forest, (6) fragmented mixed forest, (7) open scrub, (8) scrubland, (9) grassland and (10) woodland. The weights assigned for each class are given in Table 3 .

\section{Other thematic layers}

The roads shape file was extracted as per the study area. Buffer was generated using Euclidean distance in ARC GIS spatial analyst. The weights given for each buffer ring are given in Table 4.

Table 4. Weights assigned for road buffer

\begin{tabular}{|l|c|}
\hline \multicolumn{1}{|c|}{ Road buffer } & Assigned weight \\
\hline Buffer $0-1 \mathrm{~km}$ & 2 \\
\hline Buffer $1-2 \mathrm{~km}$ & 3 \\
\hline Buffer $2-3 \mathrm{~km}$ & 4 \\
\hline Outside $3 \mathrm{~km}$ buffer & 5 \\
\hline
\end{tabular}

Drainage layer was extracted from DEM of the study area using ARC GIS Hydrology tool. Each order of drainage was assigned a weight as given in Table 5 .

Table 5. Weights assigned for drainage buffer

\begin{tabular}{|l|c|}
\hline \multicolumn{1}{|c|}{ Drainage buffer $(100 \mathrm{~m})$} & Assigned weight \\
\hline First order & 5 \\
\hline Second order & 4 \\
\hline Third order & 3 \\
\hline Fourth order & 2 \\
\hline Fifth order & 2 \\
\hline Outside buffer & 1 \\
\hline
\end{tabular}

Slope data was extracted from DEM in ARC GIS (surface tool) for the study area and used in the analysis. The weights assigned for each class is given in Table 6 .

Table 6. Weights assigned for slope class

\begin{tabular}{|l|c|c|}
\hline \multicolumn{1}{|c|}{ Slope class } & Percent slope & Assigned weight \\
\hline Water (nearly level) & $0 \%$ & 1 \\
\hline Gentle & $0-5 \%$ & 2 \\
\hline Moderate & $5-10 \%$ & 5 \\
\hline Strong & $10-25 \%$ & 4 \\
\hline Steep & $25-35$ & 3 \\
\hline Very steep & $>35 \%$ & 2 \\
\hline
\end{tabular}


Lakes thematic layer was downloaded from DIVA GIS. A subset of this layer was extracted according to the study area. Weights assigned for each buffer class are given in Table 7.

Table 7. Weights assigned for lake buffer

\begin{tabular}{|l|c|}
\hline \multicolumn{1}{|c|}{ LAKE buffer } & Assigned weight \\
\hline Buffer $0-1.5 \mathrm{~km}$ & 5 \\
\hline Buffer $1.5-3 \mathrm{~km}$ & 4 \\
\hline Buffer $3-4.5 \mathrm{~km}$ & 3 \\
\hline Buffer $4.5-6 \mathrm{~km}$ & 2 \\
\hline Outside $6 \mathrm{~km}$ buffer & 1 \\
\hline
\end{tabular}

These thematic layers were integrated (along with their weights) in model maker using ERDAS Imagine to obtain a composite map of wildlife suitability. The

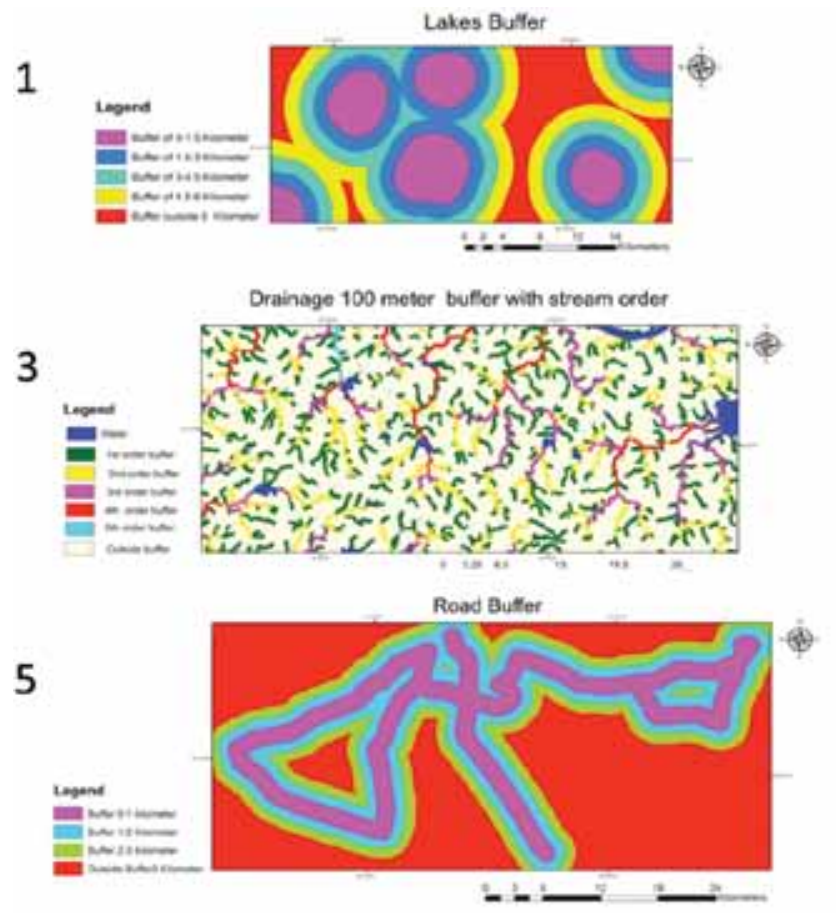

explaining the methodology of the study procedure is presenting at the Figure 2. The final map shows areas of high suitability, moderate suitability, low suitability and no suitability. Figure 3 shows the various thematic layers used.

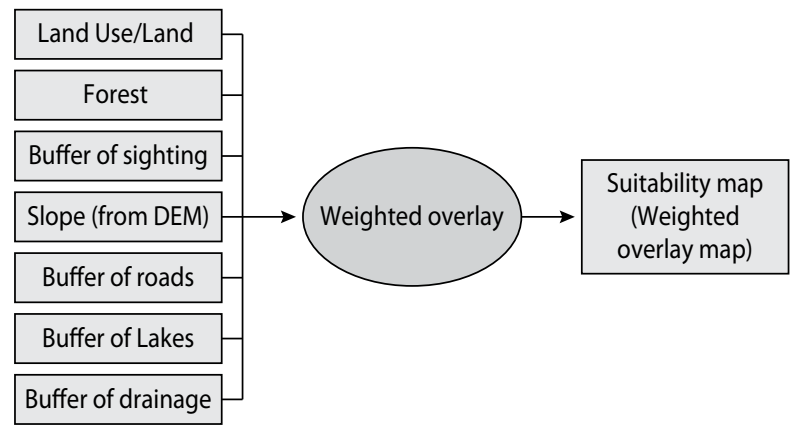

Figure 2. Flow chart explaining the methodology of the study

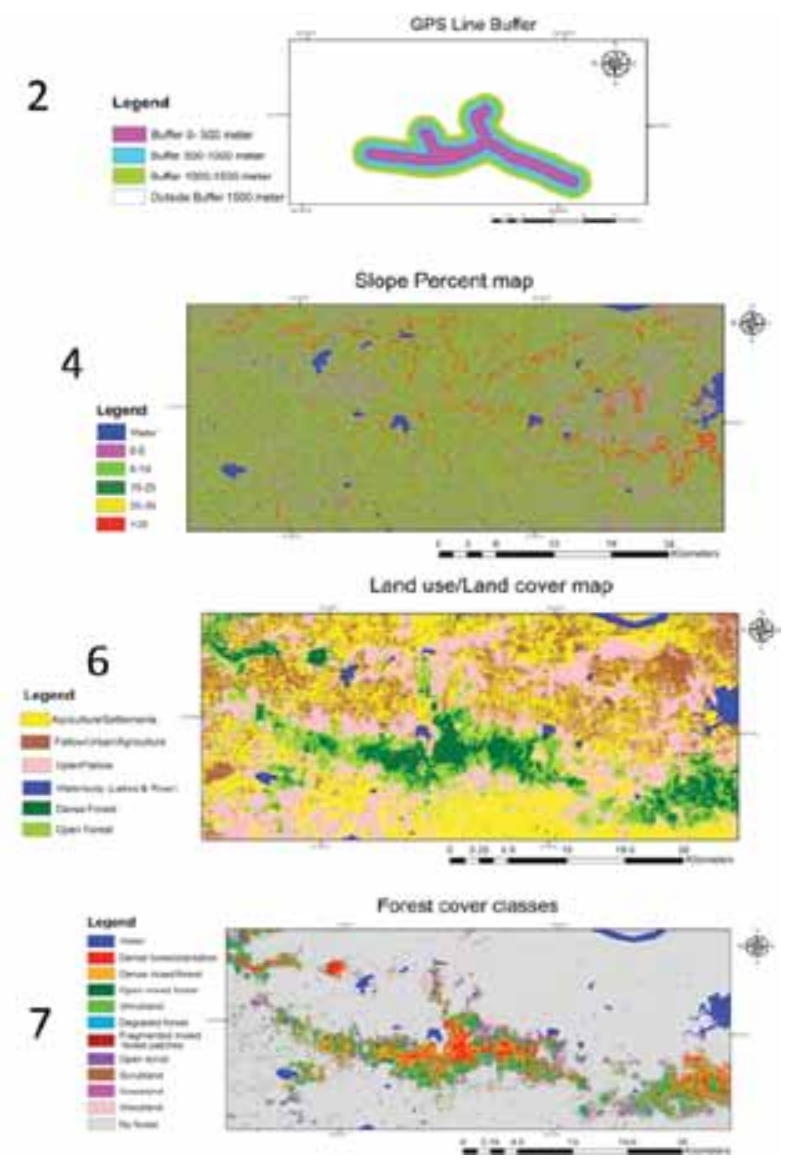

Figure 3. Various thematic layers used: (1) lakes buffer, (2) GPS line buffer, (3) drainage buffer, (4) slope map, (5) road buffer, (6) LULC map and (7) forest cover map 


\section{Results AND DISCUSSION}

According to the obtained results, of the total analysed area, highly suitable area was found to be $2.45 \%$, moderately suitable area constitutes an area of $12.0 \%$ and least suitable area was found to be $16.2 \%$.

\section{Dadri/Kotwa forest}

It is the densest of the ranges. It is endowed with rich biodiversity and known for medicinal plants (Singh and Narain 2009). The terrain consists of short heighted hills with gentle slopes. The hill tops are still inaccessible and are thus good habitat for wildlife.

\section{Darhi Ram forests}

Moderately suitable areas were found in these forests, which are highly disturbed because of increasing pressure of urbanisation. The outer fringes of these forests are highly fragmented and form the least suitable habitat for wildlife. Urbanisation has increased settlements and agricultural plots. The forested region should be protected, as they provide food and shelter to the wild animals; if destroyed then they will move towards the human settlements.

\section{Kotwa-Patewar-Lalgani forests}

At Kotwa, there is a plantation taken care by the forest officials occurring along with mixed forest. However, it is observed as highly suitable habitat for the wildlife. Forests at higher elevation in Patewar have reported to be highly suitable for wildlife. Lalganj forests are highly disturbed because of urbanisation. It provides moderately suitable habitat for wild animals. The outer edges of these forests provide the least suitable areas for wildlife existence. They should be protected such that the wildlife habitat is safeguarded against further deterioration. The fragmented forest patches should be connected such that they are protected against isolation. It will provide a corridor for wildlife movement. Good conservation practices can transform them into highly suitable areas.

\section{Sarson forests}

Adjoining the Darhi Ram forests is the Sarson forest where good presence of bears has been noted. Hill tops are seen to be highly suitable areas, and surrounding forests provide moderately suitable habitat. A large proportion of forests observed as least suitable habitat are the outer margins of the forests. If protected properly, it can be converted into a moderately suitable habitat for wildlife movement.

\section{Not suitable area}

It constitutes $67.08 \%$ of the total area analysed. Mostly agriculture and fallow areas were found to constitute this area.

\section{Conclusion}

The study has enlightened the role of geospatial technology in identifying potential wildlife habitat. This is the first step towards any conservation programme. The use of coarse resolution satellite data such as Landsat OLI data and various thematic layers available in public domain can be used by forest managers and conservationist. Geospatial technology provides the potential for accurate, time-saving and cost-effective methodology to solve wildlife conservation problems.

\section{ACKNOWLedgement}

The authors are grateful to landsat.usgs.gov for providing the Landsat satellite data used for analysis in the study and www.diva-gis.org for providing various GIS data. We also thank the World Wide Fund for Nature (WWF) for their financial support. We also appreciate the Vindhya Bachao members, Shri Shiva Kumar Upadhayaya and Mukesh Kumar, for their efforts in ground truth collection.

Short communication was prepared (by Małgorzata Sułkowska - Assistant Editor, Folia Forestalia Polonica, Series A - Forestry) on the basis of:

The original paper, which was published in Eurasian Journal of Forest Science, 2017, 5 (1), 13-28: Laxmi, G., Firoz, A. and Debadityo, S. Wildlife Habitat Suitability Analysis around Madihan Forest, Mirzapur District, Uttar Pradesh, India: A Geospatial Approach. 


\section{References}

Arc GIS version 10.0 (1999-2010) ESRI Inc.(www.esri. com).

Areendram, G., Krishna, R., Mazumdaar, S. 2011. Geospatial modelling to assess elephant habitat suitability and corridors in Northern Chhattisgarh, India. Tropical Ecology, 52 (3), 275-283.

Bhat, S.D., Rawat, G.S. 1995. Habitat use by Chital (Axis axis) in Dhaulkhand, Rajaji National Park, India. Tropical Ecology, 36 (2), 177-189.

Champion, H.G, Seth, S.K. 1968. A revised classification of the Forest Types in India Manager publications. GOI, New Delhi, India.

Das, M.K., Awasthi, A.K., Pandey, R., Dwivedi, A., Koul, M. 2007. Mapping of forest types and land use/land cover of Singrauli coal field area using satellite remote sensing techniques. Journal of Tropical Forestry, 23, 141-150.

De Fries, R., Hansen, A., Newton, A.C., Hamsen, M.C. 2005. Increasing isolation of protected areas in tropical forests over the past 20 years. Ecological. Applications, 15 (1), 19-26.

ERDAS Imagine, 9.0 2005. ERDAS field guide. Copyright Leica Geosystems Geospatial Imaging, LLC. (1991-2005). Printed in USA.

Goparaju, L., Sinha, D. 2015. Forest cover change analysis of dry tropical forests of Vindhyan highlands in Mirzapur district, Uttar Pradesh using satellite remote sensing and GIS. Ecological Questions, 22, 23-37.

Javed, A., Khan, I. 2012. Landuse/Land cover change due to mining activities in Singrauli Industrial belt, Madhya Pradesh using remote sensing and GIS. Journal of Environmental Research and Development, 6, 521-529.

Johnsingh, A.J.T., Joshua, J. 1994. Conserving Rajaji and Corbett national Parks: the Elephant as a flagship species. Orya, 28, 135-140.

Kamat, D.S. 1986. An integrated approach to remote sensing studies for wildlife habitat evaluation. In: Proceedings of seminar cum workshop on wildlife habitat evaluation using remote sensing techniques (eds.: D.S. Kamat, H.S. Panwar). IIRS, Dehradun, 165-182.
Khanna, V., Ravichandran, M.S., Kushwaha, S.P.S. 2001. Corridor analysis in Rajaji -Corbett Elephant reserve. A remote sensing and GIS approach. Journal of the Indian Society of Remote Sensing, 29, 41-46.

Kushwaha, S.P.S., Khan, A., Habib, B., Quadri, A., Singh, A. 2004. Evaluation of Sāmbhar and Muntjak habitats using geostatistical modelling. Current Science, 86, 1390 -1400.

Kushwaha, S.P.S., Hazarika, R. 2004. Assessment of habitat loss in Kameng and Sonitpur elephant reserves. Current Science, 87, 1447-1453.

Lillisend, T.M., Keifer, R. 2004. Remote sensing Image interpretation. John Wiley, New York.

Mishra, C., Johnsingh, A.J.T. 1996. On habitat selection by the Goral (Naemorhaedus goral) bedfordi (Bovidae Artiodactyla). Journal of Zoology, 240, 573-580.

Mondal, P., Southwoth, J. 2010. Protection versus commercial management spatial and temporal analysis of land cover changes in the tropical forests of central India. Forest Ecology and Management, 259 (5), 1009-1017.

Murphy, P.G., Lugo, A.E. 1986. Ecology of tropical dry forest. Annual Review of Ecology and Systematics, 17, 67-88.

Nandy, S., Kushwaha, S.P.S., Mukhopadhyaya, S. 2007. Monitoring the Chilla-Motichur wildlife corridor using geospatial tools. Journal for Nature Conservation, 15, 237-244.

Raghubanshi, A.S., Tripathi, A. 2009. Effect of disturbance, habitat fragmentation and alien invasive plant on floral diversity in dry tropical forest of Vindhyan highlands: a review. Tropical Ecology, 50, 57-69.

Singh, A. 2007. Revegetation of coal mine spoils using Prosopsis juliflora in Singrauli coal field is a harmful practice from ecological viewpoint. Current Science, 93, 1204.

Singh, U. Narain, S. 2009. Ethnobotanical wealth of Mirzapur district, U.P. Indian Forester, 135 (2), 185-197.

Yadav, P.K., Kapoor, M., Sarma, K. 2012. Land use land cover mapping change detection and conflict analysis of Nagzira-Navegaon corridor, Central India using Geospatial Technology. International Journal of Remote Sensing and GIS, 1 (2), 90-98. 